\title{
小唾液腺の腺腫様過形成における細胞増殖能の検討および文献的考察
}

\author{
大内知之·安彦善裕・齊藤正人・藏口潤 \\ 西村学子・荒井滋朗. 小川優・佐藤昌明* \\ 小浜源 郁**賀来 亨
}

\section{Adenomatoid hyperplasia of minor salivary glands: Analysis of proliferative activity and a review of the literature}

\author{
Tomoyuki Ohuchi - Yoshihiro Abiko - Masato Saitoh - Jun Kuraguchi \\ Michiko Nishimura - Jiro Arai - Masaru Ogawa - Masaaki Satoh* \\ Gen-iku Kohama** ${ }^{* *}$ Tohru KaKU
}

\begin{abstract}
Adenomatoid hyperplasia is an uncommon clinicopathological entity, which is a non-neoplastic, non-inflammatory enlargement of the minor mucous salivary glands. This lesion presents clinically as an asymptomatic tumor-like nodule that is characterized microscopically by a proliferation of minor salivary gland tissue. Very few reports of this lesion have appeared in the literature, and the proliferative activity of adenomatoid hyperplasias has not been studied previously.

The number of argyrophilic nucleolar organizer regions (AgNOR) can be used to study the degree of cell proliferative activity. The mean number of AgNOR increased in a stepwise fashion from normal salivary glands $(1.47 \pm 0.05)$ to adenomatoid hyperplasia $(1.58 \pm 0.05)$ and pleomorphic adenomas $(1.73 \pm 0.07)$. The clinical features also were discussed with a review of the literature.
\end{abstract}

Key words: adenomatoid hyperplasia（腺腫様過形成）, minor salivary gland（小棰液腺）, proliferative activity (增殖活性), sensitive AgNOR

緒 言

小喠液腺の腺腫様過形成は, 非炎症性・非腫瘍性の 増殖性病変である.その肉眼的所見から臨床的には腫 瘍性病変を疑わせるが, その本態は固有小唾液腺の過 形成であり，口蓋部に発生することが多いとされてい $ろ^{1)} .1991$ 年にBuchner ら ${ }^{2)}$ が 40 例を, 1995 年に
Barrett and Speight ${ }^{3)}$ が 20 例を臨床統計的にまと めた報告があるが, それ以外の報告例は少ない4 16). 本疾患はその組織学的所見および臨床経過より良性病 変とされているが, 発生機序, 増殖能を含めその本態 について不明な点も少なくない. 今回われわれは, 正 常唾液腺および良性唾液腺腫瘍との病理組織学的比較 検討および文献的検索を行い, 本疾患の細胞増殖能を
北海道医療大学歯学部口腔病理学講座

（主任 : 賀来 亭教授）

*札幌医科大学医学部附属病院病理部

(主任 : 森 道夫部長)

${ }^{* *}$ 札幌医科大学医学部口腔外科学講座

(主任 : 小浜源郁教授)

Department of Oral Pathology, School of Dentistry, Health Sciences University of Hokkaido
(Chief: Prof. Tohru Kaku)

*Department of Clinical Pathology, School of Medicine, Sapporo Medical University (Chief: Prof. Michio Mori)

**Department of Oral and Maxillofacial Surgery, School of Medicine, Sapporo Medical University (Chief: Prof. Gen-iku Kohama)

受付日：平成 8 年 7 月 5 日 
含む臨床病理学的特徵を考察した。

\section{研究対象および方法}

\section{1. 研究対象}

検索には口蓋に生じた腺腫様過形成 2 例を用いた。 また対照には下唇に生じた粘液囊胞に付随した小睡液 腺組織 2 例および小唾液腺（上唇・蓋）に生じた多 形性腺腫 3 例を用いた.

腺腫様過形成・症例 1 は 53 歳男性例. 数年前より 自覚放置していた右側硬・軟口蓋移行部の約 $5 \times 8$ $\mathrm{mm}$ の無茎性腫瘤を通院中の歯科医院で, 口蓋部良性 腫瘍の疑いにて摘出. 腫瘤の表面粘膜は健常部と同色, 弾性硬. 可動性を認めず周囲組織との連続性もなく術 後の経過は良好。

腺腫様過形成・症例 2 は 22 歳の男性例，通院中の 歯科医院にて左側軟口蓋部に約 $20 \times 15 \mathrm{~mm}$ の無茎性 腫瘤を指摘される, 腫瘤表面は健常粘膜色で, 弾性軟. 軟口蓋部腫瘍の疑いのもと 1980 年—医科大学附属 病院歯科口腔外科にて摘出. 術後の経過は不明.

\section{2. 研究方法}

\section{1 ) 組織}

摘出組織は $10 \%$ 中性緩衝ホルマリン溶液にて, 24 48 時間浸漬固定後通法どおり硬パラフィン包埋 し, 約 $4 \mu \mathrm{m}$ の薄切切片としたものを用いた. 病理組 織学的検索にはへマトキシリン・エオジン (H-E) 染 色, PAS 染色およびムチカルミン染色を用いた.

2 ) Sensitive AgNOR 染色法による細胞増殖能の 検討

細胞増殖能の検索には Yekeler ら ${ }^{17)}$ の Sensitive AgNOR 染色法を改良して行ない, その評価を行った. すなわち脱パラ洗浄した切片を, $1 \%$ 蟻酸にて溶解し た $2 \%$ ゼラチンと $50 \%$ 硝酸銀を $1: 2$ の比率で混合し た溶液に, 室温暗室下にて 30 分間浸漬する. 洗浄後, 脱イオン水を通し, チオ硫酸ナトリウムで 3 分間定着 を行う. 定着後水洗し, Blue toning 溶液 $\left(\mathrm{FeCl}_{3}\right.$ $30 \mathrm{mM} / 1, \mathrm{~K}_{3} \mathrm{Fe}(\mathrm{CN})_{6} 11 \mathrm{mM} / 1$, Oxalic acid 33 $\mathrm{mM} / 1) に 2$ 秒間通す. その後脱イオン水にて充分洗 浄・浸漬した後, 脱水・透徹・封入を行なった。計測 部位は腺腫様過形成および粘液囊胞に付随した小睡液 腺では, 腺房細胞および近接した導管部の細胞を用い た. 粘液囊胞症例に付随した小唾液腺組織は, $\mathrm{HE}$ 染 色で導管の拡張および腺房の萎縮や炎症性変化のみら れない, ほほ正常に近いと思われる部位を用いた。.多 形性腺腫は粘液腫様組織や軟骨様組織部位以外の充実 性および腺管状の上皮細胞の部位で計測を行なった. 評価方法は, 1 か所につき 500 個の細胞で核内ドット 数を計測し, 細胞核 1 個あたりのドット数を求め, 1 症例につき 5 か所計測し，その平均值を用いた。

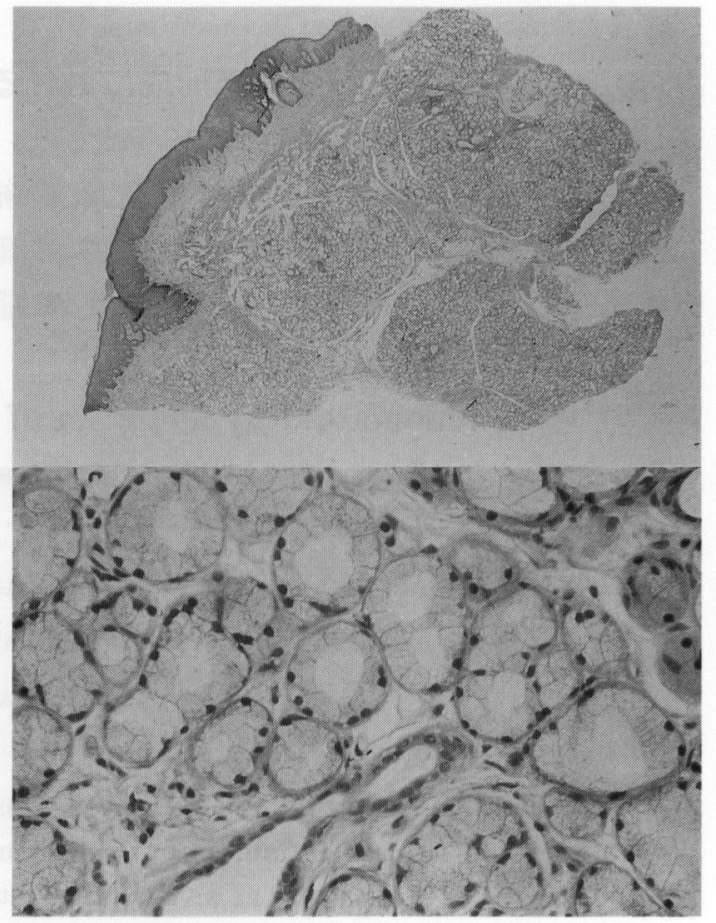

写真 1 腺腫様過形成の病理組織像（症例 1, H-E 染色） 上; ルーペ像. 口蓋粘膜上皮下に, 小葉構造を呈する唾液 腺組織を認める

下; 強拡大像. 正常な唾液腺構造を認める. 細胞異型は認 めない.

\section{3 ) 文献検索}

臨床統計学的検索には涉猟し得た 15 編 84 症例から 年齢, 性別, 発生部位, 大きさ, 性状, 臨床診断, 治療 経過について検索した。

\section{結果}

\section{1. 病理組織学的所見}

症例 1 : 摘出組織は一部錯角化し, 軽度の上皮脚延 長を認める重層扁平上皮に被覆された腫瘤状を呈して いた. 上皮下には毛細血管や脂肪組織を伴った結合組 織がみられ，その下に粘液腺の増生が認められる．粘 液腺組織は比較的大きな小葉単位からなり，小葉間は 少量の線維性結合組織で境されており腫瘤の本体はこ の粘液腺の増生と考えられる。一部萎縮している部位 が認められるが, 核異型を含む細胞異型, 構造異型お よび細胞分裂像はほとんど観察されなかった（写真 1 上下). また炎症性細胞浸潤や, 毛細血管の増生・拡張 · 充血もほとんど認められなかった.PAS 染色および ムチカルミン染色でも正常粘液腺と同様の性状を示し た。 


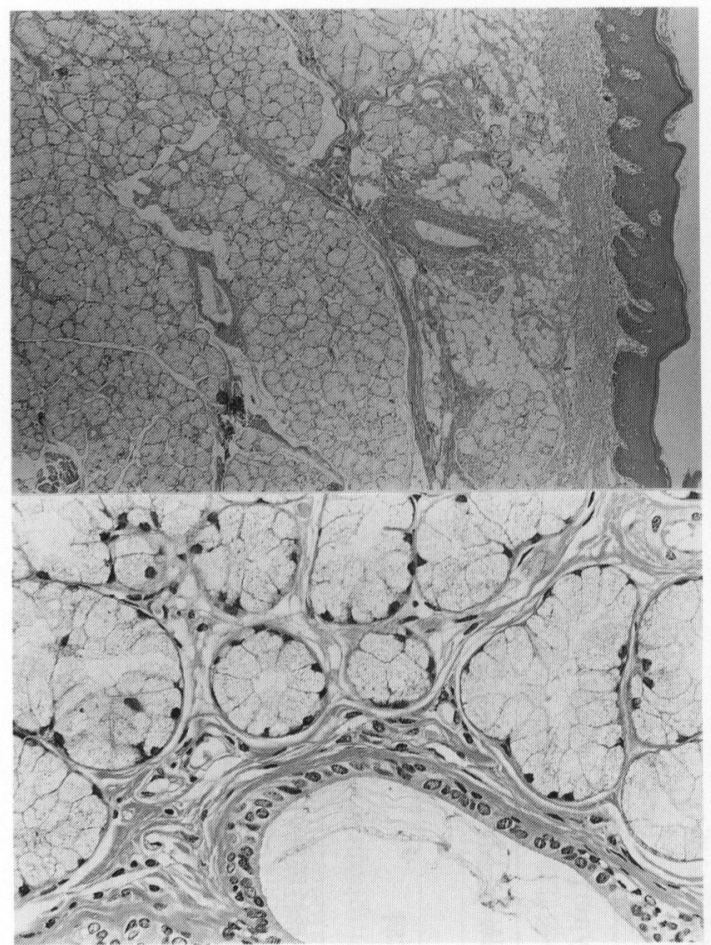

写真 2 腺腫様過形成の病理組織像（症例 $2, \mathrm{H}-\mathrm{E}$ 染色） 上; 弱拡大像, 下; 強拡大像. 軽度の導管拡張は認められ るが, 細胞異型は認めない.

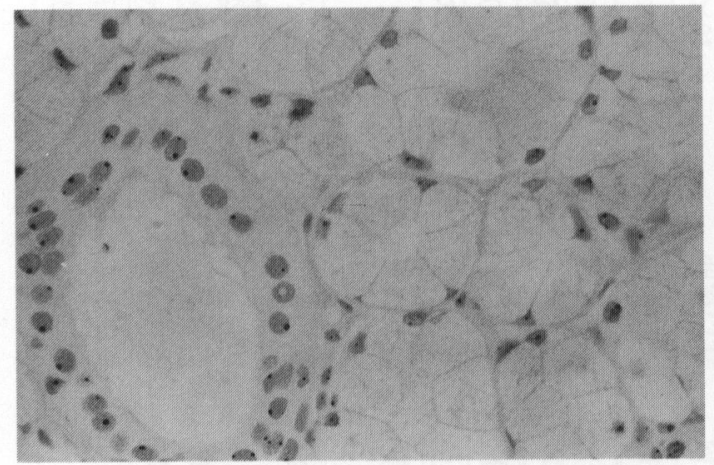

写真 3 腺腫様過形成 (症例 1 ) の sensitive AgNOR 染色所見. 細胞核内に $1 \sim 2$ 個のドットが認めら れる。

症例 2 : 軽度の錯角化を呈する重層扁平上皮に被覆 されており，上皮下に毛細血管や導管を認める膠原線 維束を主体とする一層の結合組織層が認められる. 結 合組織層下には脂肪組織がみられ, その下に粘液腺の 増生が認められる. 粘液腺は小葉構造をとり, 導管お よび神経線維束の比較的目立つ小葉間結合組織に境さ れている. 粘液腺に細胞・組織異型および細胞分裂像

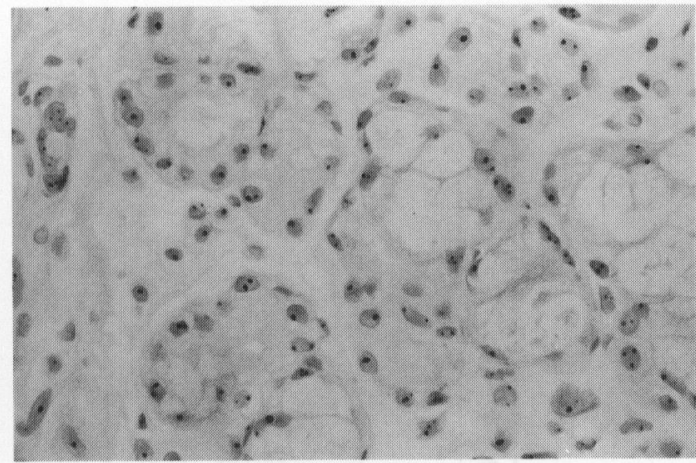

写真 4 粘液囊胞付随の小唾液腺 sensitive AgNOR 染色所見.

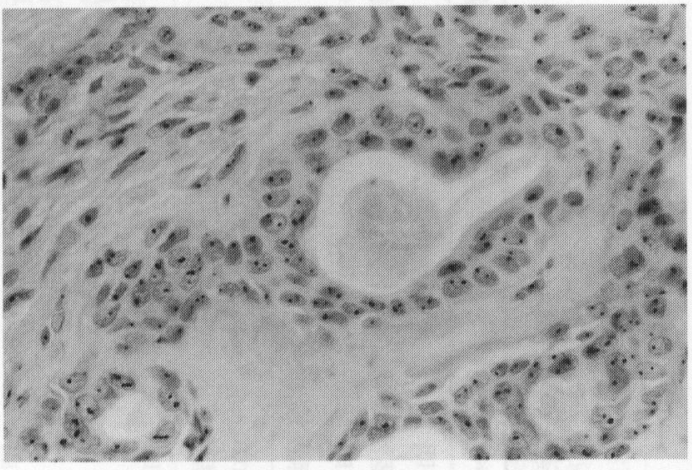

写真 5 多形性腺腫

sensitive AgNOR 染色所見.

表 1 核 1 個あたりの平均 $\mathrm{AgNOR}$ 数

\begin{tabular}{lc}
\hline 病理組織診断名 & 平均 $\mathrm{AgNOR}$ 数士標準偏差 \\
\hline 小喠液腺の腺腫様過形成 $(\mathrm{n}=2)$ & $1.58 \pm 0.050$ \\
多形性腺腫 $(\mathrm{n}=3)$ & $1.73 \pm 0.073$ \\
(上唇および口蓋) & \\
正常小唾液腺 $(\mathrm{n}=3)$ & $1.47 \pm 0.049$ \\
(下口唇粘液囊胞 $)$ &
\end{tabular}

や炎症性変化もほとんどみられないが, 導管は全体的 に拡張傾向にあった (写真 2 上下). PAS 染色および ムチカルミン染色は症例 1 と同様の所見であった.

\section{AgNOR 染色による細胞増殖能の検討}

粘液囊胞周辺の正常唾液腺組織, 腺腫様過形成, お よび多形性腺腫において, AgNOR ドットの形態はと もに比較的均一な円形一楕円形であり, 核小体と一致 するタイプの大きく明瞭なドットを主体としていた (写真 $3 \sim 5$ ). $A g N O R$ 数は正常小唾液腺 : $1.47 \pm$ 


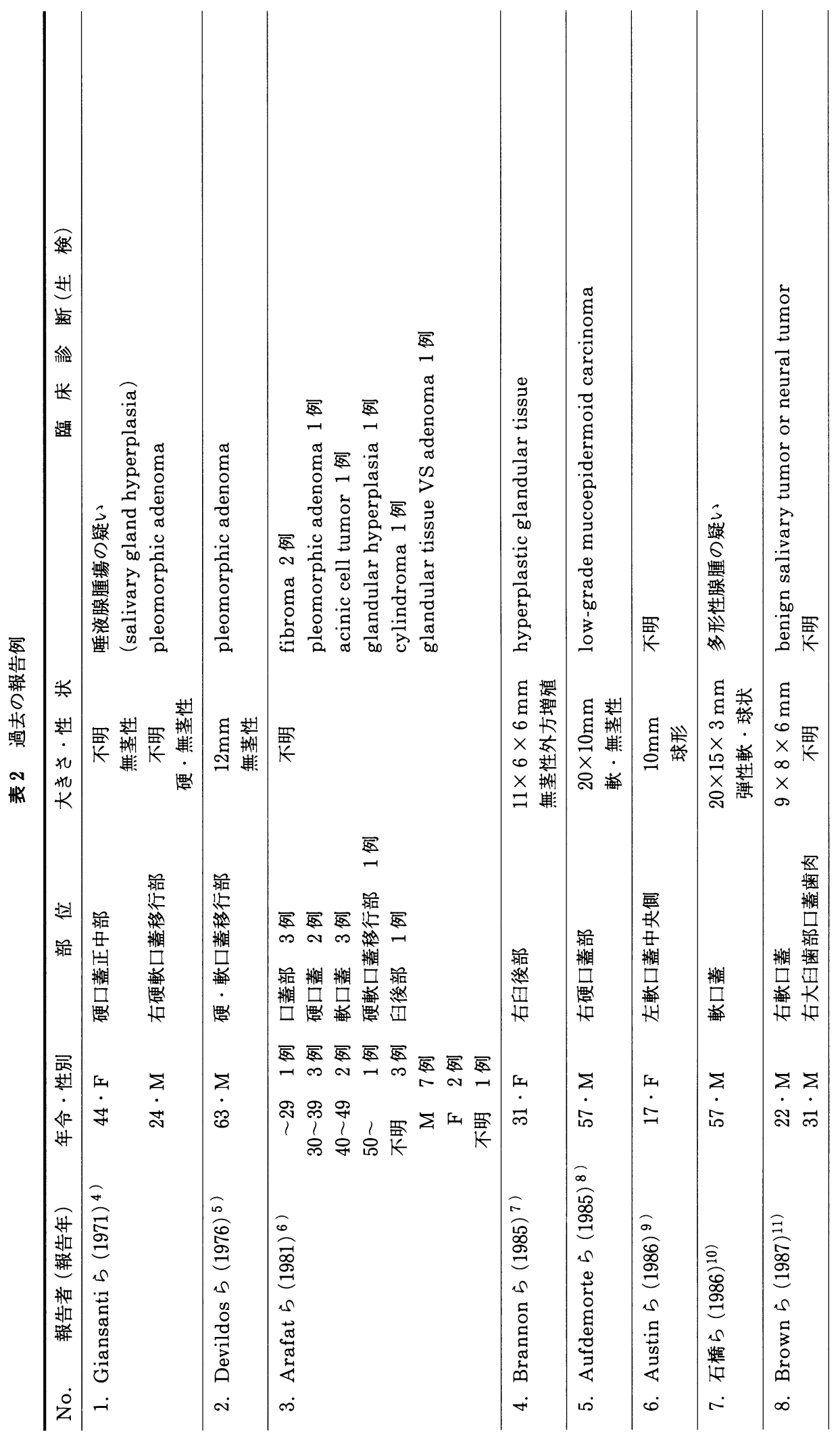


घำ 릉 $\frac{\pi}{60} \overrightarrow{0}$ $\frac{\pi}{b 0}$ व

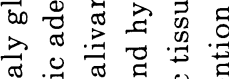
$\stackrel{\pi}{2}$ 品

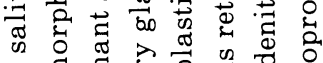

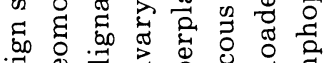

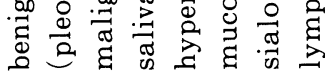

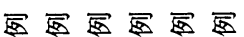

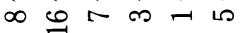

$\xi$

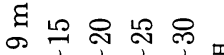

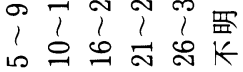

區

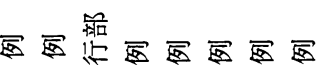
등 $\mathrm{N}$ 的工

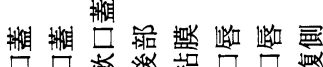

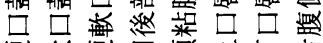

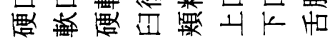

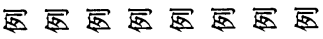

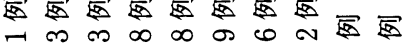

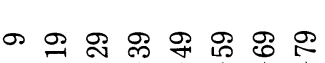

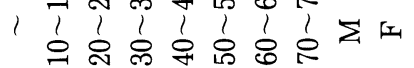

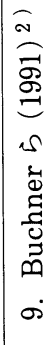

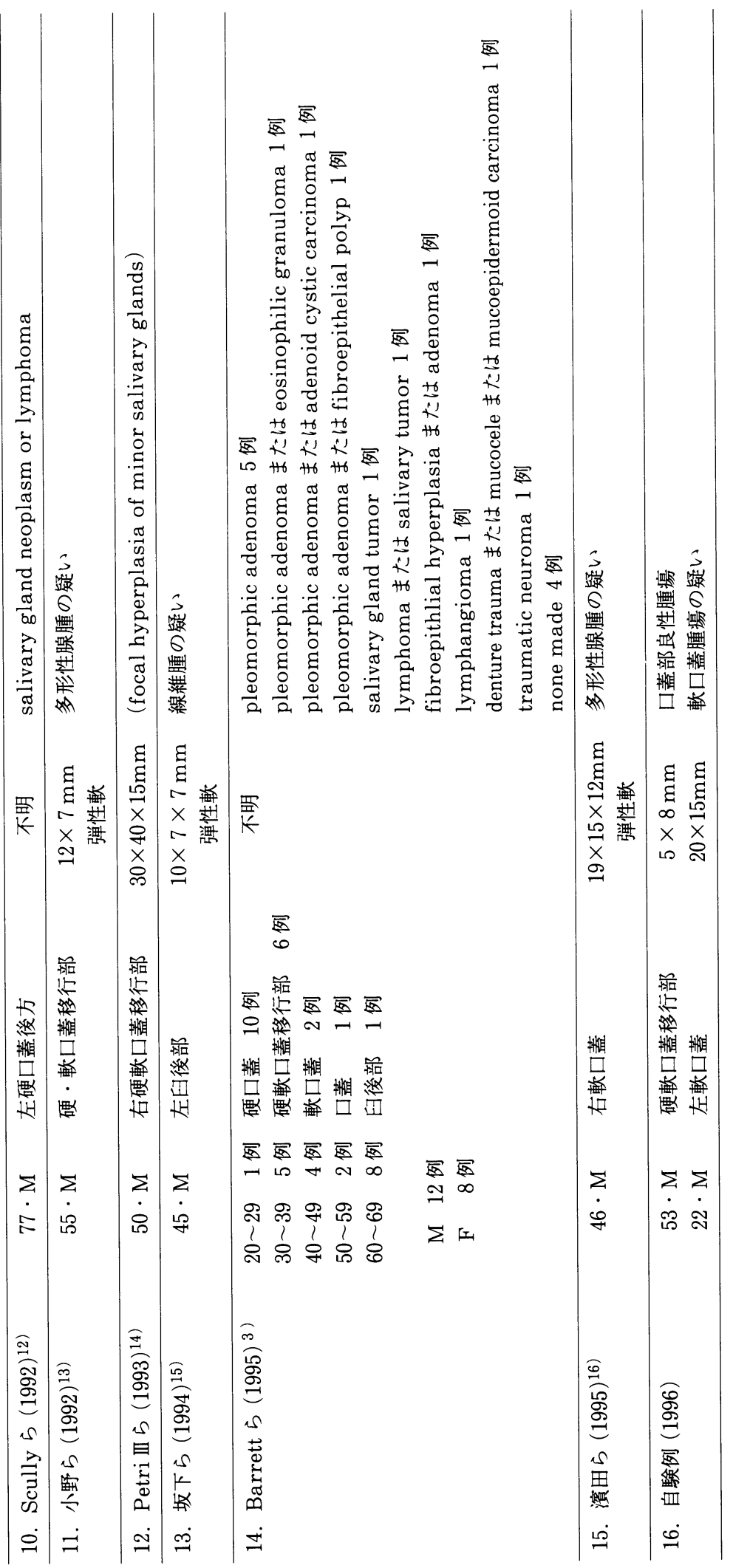


表 3 年齢

\begin{tabular}{c|c}
\hline 摘出時年齢 $($ 歳 $)$ & 症例数 $(\%)$ \\
\hline $0 \sim 9$ & $1(1.2)$ \\
$10 \sim 19$ & $4(4.8)$ \\
$20 \sim 29$ & $8(9.6)$ \\
$30 \sim 39$ & $18(21.7)$ \\
$40 \sim 49$ & $17(20.5)$ \\
$50 \sim 59$ & $17(20.5)$ \\
$60 \sim 69$ & $15(18.1)$ \\
$70 \sim 79$ & $3(3.6)$ \\
\hline
\end{tabular}

表 4 発現部位

\begin{tabular}{l|c}
\hline \multicolumn{1}{c|}{ 部 位 } & 症例数 $(\%)$ \\
\hline 硬口蓋 & $32(37.2)$ \\
軟口蓋 & $21(24.4)$ \\
硬·軟口蓋移行部 & $17(19.8)$ \\
口蓋 & $5(5.8)$ \\
下顎臼後三角 & $6(7.0)$ \\
煩粘膜 & $2(2.3)$ \\
上口唇 & $1(1.2)$ \\
下口唇 & $1(1.2)$ \\
舌 & $1(1.2)$ \\
\hline
\end{tabular}

表 5 初診時の大きさ

\begin{tabular}{c|c}
\hline 大きさ $(\mathrm{mm})$ & 症例数 $(\%)$ \\
\hline $5 \sim 9$ & $10(21.3)$ \\
$10 \sim 15$ & $21(44.7)$ \\
$16 \sim 20$ & $11(23.4)$ \\
$21 \sim 25$ & $3(6.4)$ \\
$26 \sim 30$ & $2(4.3)$ \\
\hline
\end{tabular}

0.05 , 腺腫様過形成 : $1.58 \pm 0.05$, 多形性腺腫 $1.73 \pm$ 0.07 と腺腫様過形成の AgNOR 数は正常唾液腺より 大きい值を, 多形性腺腫より小さい值を示した（表 1 ).

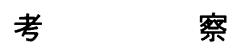

小唾液腺の腺腫様過形成は 1971 年に Giansanti ら 4 ）によって臨床的に腫瘍状を呈する粘液性小唾液 腺病変として, 口蓋に生じた 2 例がはじめて報告され た. 本疾患は以後まれな疾患として報告されている が2 16)，いずれも臨床的には，口蓋部をはじめとする 口腔粘膜に, 腫瘤状・結節状に発生し唾液腺腫瘍を疑
わせるが, 病理組織学的には正常な小睡液腺組織の過 形成からなる病変である. Buchner ら ${ }^{2)}$ は, 過去に minor salivary gland hyperplasia, minor salivary gland hypertrophy, salivary glandular hyperplasia, adenomatous hyperplasia of minor salivary glands および adenomatoid hyperplasia of mucous salivary glands と診断された症例を組織学 的に再確認し，同一疾患として報告している．本疾患 には多彩な診断名が付されてきたが4〜6，9，10，13)，そ の本態は同様のものであり, 本疾患に該当すべき症例 が潜在的に存在することが推測される. 自験例を含む 涉猟しえた症例をまとめると（表 2 ), 年齢は 30 代か ら 60 代が全体のほほ 8 割を占めており，平均年齢は 約 45 歳であった。性別では男性が約 65\%, 女性が約 $35 \%$ と中年期男性に多い傾向が認められた（表 3 ). 発 生部位の約 9 割が口蓋部であり（表 4 ）, 大きさは最大 径 15 20mm の症例が全体の約 9 割を占めていた. 性 状 (形状) は, 弾性硬または弾性軟の広基性腫瘤とし て認められたものが多く，ほとんどが健常色を呈する 口腔粘膜に完全に被覆されていたが, 軽度の赤色や青 色を呈する症例も認められた. また潰瘍形成も数例で 認めた（表 5 ). 臨床診断名は良性唾液腺腫場を疑った ものが最も多く，良性悪性を含む喠液腺腫瘍を疑った ものが半数以上に及んだ。一方, 腫瘍性病変以外の唾 液腺の過形成および増殖性病変, 外傷などによる反応 性病変などが数例づつあった. また, 無症候性に経過 するのも本疾患の特徵であり, 一般歯科受診中に発見 された症例も少なくない $3,7,8,15)$. 組織学的には正 常組織と同様の所見であった. Scully ら ${ }^{12)}$ の潰瘍部 に帯状のリンパ球浸潤を認めた症例以外, 特徽的な炎 症所見はみられず, 線維化, 萎縮, 導管拡張, 粘液漏出 などもあるが，いずれもおおむね軽度であった．治療 効果は摘出 12 年後に粘表皮癌を生じた報告例が 1 例 あるが 6$)$ ，これは本疾患摘出部と反対側口蓋に発生し たもので, 本疾患との関係は疑問で, それ以外は術後 3 か月〜 10 年で再発例は 1 例もなく, 良好であった. 文 献的考察からも本疾患は緩慢な発育を示す病変である と推測でき, 今回の増殖能の検討で得られた結果も症 例数は少ないが, これを指示するものと思われた. 本 疾患に関してArafat $5^{6)}$ やAufdemorte 5 ${ }^{8)}$ はほ とんどの症例で, 既往に外傷などもなく, 全身的な要 因も認められないことから特発性増殖の可能性を述べ ている.また, Barrett ら ${ }^{3)}$ は喫煙習慣および上顎義 歯の使用すなわち慢性炎症, 局所的外傷との関係が本 症発生の要因となる可能性を指摘している. その他に も喫煙習慣のある患者 $8,10,16)$ や義歯使用患者での報 告があり $5,10,12)$ ，喫煙習慣や義歯装着などの長期間に 及ぶ複数の軽微な刺激が, 本症の発生要因のひとつと なっている可能性も考えられた。

一方, One-step 法の開発・改良により AgNOR 染 
表 6 初診時臨床 (仮) 診断名

\begin{tabular}{|c|c|}
\hline 臨床（仮）診断名 & 症例数 \\
\hline 多形性腺腫 & 11 \\
\hline $\begin{array}{l}\text { 多形性腺腫または他の疾患 } \\
\quad \text { (好酸性肉芽腫） } \\
\quad \text { (腺様囊胞癌） } \\
\quad(\text { 線維上皮性ポリープ） }\end{array}$ & 3 \\
\hline 良性唾液腺腫瘍 & 1 \\
\hline 良性唾液腺腫瘍または神経系腫瘍 & 1 \\
\hline 唾液腺腫瘍 & 3 \\
\hline 悪性唾液腺腫瘍 & - \\
\hline 低悪性度粘表皮癌 & 1 \\
\hline 腺房細胞腫 & 1 \\
\hline 腺様囊胞癌 & 1 \\
\hline 喠液腺腫瘍またはリンパ腫 & 1 \\
\hline リンパ腫または唾液腺腫瘍 & 2 \\
\hline リンパ管腫 & 1 \\
\hline リンパ増殖性疾患 & - \\
\hline 線維腫 & 3 \\
\hline 線維増殖性過形成または腺腫 & 1 \\
\hline 腺組織または腺腫 & 1 \\
\hline 腺過形成 & 1 \\
\hline 腺組織過形成 & 1 \\
\hline 局所的小睡液腺過形成 & 1 \\
\hline 唾液腺過形成 & - \\
\hline 過形成組織 & - \\
\hline 外傷性神経腫 & 1 \\
\hline 義歯による外傷または粘液囊胞 & \\
\hline または粘表皮癌 & 1 \\
\hline 粘液貯留状態 & - \\
\hline 唾液腺炎 & - \\
\hline 診断名なし & 4 \\
\hline
\end{tabular}

色は, 腫瘍性病変の悪性度や予後評価の指標として, その有用性が示され唾液腺腫㿠でも多くの報告例があ

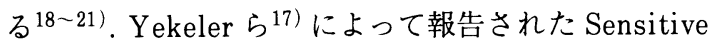
AgNOR 染色法は高感度にAgNOR ドットを識別す ることが可能とされ，今回われわれは同法を応用し， 検討した． 2 症例のみで明確な言及はできないが，本 症例は正常唾液腺組織と良性腫瘍である多形性腺腫と の中間的な数值を示し, 正常組織より活発な増殖能を 有し, 異型性を示さずに緩徐かつ持続的な増殖をした 可能性が示唆された. AgNOR 染色の評価法としては, 細胞核 1 個あたりのドット数で表現することが多いが, 近年ドットの形態や分布様式も含めて評価している報 告もみられる ${ }^{22)}$. 本症のドットの形態は, 正常唾液腺 および多形性腺腫と同様に, 境界明瞭な核小体と一致 するタイプのものが多いことからも, 小唾液腺の腺腫
様過形成が良性病変であることを示唆するものと思わ れた。

$$
\text { 結語 }
$$

1. 口蓋部に生じた小唾液腺の腺腫様過形成は, 粘 液腺の増生からなり, 細胞異型および構造異型は認め られなかった。

2. 小唾液腺の腺腫様過形成の $\mathrm{AgNOR}$ ドットの 形態は均一で, 核小体と一致するタイプの大型のもの が多かった。

3. 小唾液腺の腺腫様過形成の AgNOR 数は, 1.58 \pm 0.05 で, 正常小唾液腺 $1.47 \pm 0.05$ と多形性腺腫 1.73 \pm 0.07 の中間的な値を示した。

謝辞

本研究において, sensitive AgNOR 染色はじめ標本作 製にご協力頂いた当教室の矢上了子臨床検査技師に感謝 いたします。

\section{参 考 文 献}

1) Warnock, G.R., Jensen, J.L., et al.: In: Ellis, G.L., Auclair, P.L., et al. ed. Surgical Pathology of the Salivary Glands, Philadelphia: W.B. Saunders Company, 10-25 1991

2) Buchner, A.B., Merrell, P.W., et al.: Adenomatoid hyperplasia of minor salivary glands. Oral Surg Oral Med Oral Pathol 71: 583-587 1991.

3) Barrett, A.W., Speight, P.M.: Adenomatoid hyperplasia of oral minor salivary glands. Oral Surg Oral Med Oral Pathol 79: 482-487 1995.

4) Giansanti, J.S., Baker, G.O., et al.: Intraoral, mucinous, minor salivary gland lesions presenting clinically as tumors. Oral Surg 32: 918-922 1971.

5) Devildos, L.R., Langrois, C.C.: Minor salivary gland lesion presenting clinically as tumor. Oral Surg 41: 657-659 1976.

6) Arafat, A., Brannon, R.B., et al.: Adenomatoid hyperplasia of mucous salivary glands. Oral Surg 52: 51-55 1981.

7) Brannon, R.B., Houston, G.D., et al.: Adenomatoid hyperplasia of mucous salivary glands: a case involving the retromolar area. Oral Surg Oral Med Oral Pathol 60: 188-190 1985.

8) Aufdemorte, T.B., Ramzy, I., et al.: Focal adenomatoid hyperplasia of salivary glands. A differential diagnostic problem 
in fine needle aspiration biopsy. Acta Cytologica 29: 23-28 1985.

9) Austin, M.B., Frierson Jr, H.F.: Pathologic quiz case I. Arch Otolaryngol Head Neck Surg 112: 336-339 1986.

10）石橋利文, 高坂栄一, 他：腫瘍を疑わしめた口 蓋腺過形成の 1 例. 日口外誌 32: 1042-1045 1986.

11) Brown, F.H., Houston, G.D., et al.: Adenomatoid hyperplasia of mucous salivary glands: report of two cases. J Periodontol 58: 125-127 1987.

12) Scully, C., Eveson, J.W., et al.: Adenomatoid hyperplasia in the palate: another sheep in wolf's clothing. Br Dent J 173: 141-142 1992.

13）小野芳男, 対馬壽夫, 他 : 多形性腺腫を思わせ た口蓋腺過形成の 1 例. 日口外誌 38: 496-497 1992.

14) Petri III, W.P., Carr, R.F., and Kahn, C.S.: Adenomatoid hyperplasia of the palate. J Oral Maxillofac Surg 51: 310-311 1993.

15）坂下英明, 宮田 勝, 他：臼後部に発生した小 唾液腺の腺腫様過形成の 1 例. 口科誌 43: 591 5941994.

16）濱田良樹, 濱田明子, 他：軟口蓋に発生した小 唾液腺過形成の 1 例。日口外誌 41: 838-840 1995.
17) Yekeler, H., Erel, Ö., et al.: A sensitive staining method for NORs. J Pathol 175: 449-452 1995.

18) Eagan, M.J., Clocker, J.: Nucleolar organizer regions in pathology. $\mathrm{Br} \mathrm{J}$ Cancer 65: 1 - 71992.

19) Fujita, S., Takahashi, H., et al.: Nucleolar organizer regions in malignant salivary gland tumors. Acta Pathol Jpn 42: 727-733 1992.

20) Vuhahula, E.A.M., Nikai, H., et al.: Correlation between argyrophilic nucleolar organizer region (AgNOR) counts and histologic grades with respect to biologic behavior of salivary adenoid cystic carcinoma. J Oral Pathol \& Med 24: 437-442 1995.

21) Ohuchi, T., Abiko, Y., et al.: Polymorphous low grade adenocarcinoma of minor salivary gland origin in the oral floor: Report of a case with immunohistological study and analysis of proliferative activity. Oral Med \& Pathol 1: 103-108 1996.

22) Xu, L.Z., Zhu, W.P., et al.: Studies on morphological typing of argyrophilic nucleolar organizer regions. Pathology International 45: 860-865 1995. 